Egyptian Poultry Science Journal

http://www.epsaegypt.com

ISSN: 1110-5623 (Print) - 2090-0570 (On line)

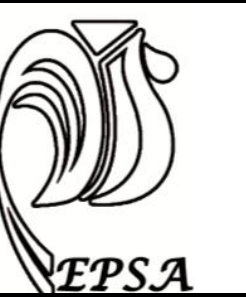

\title{
EVALUATION OF PRODUCTIVE AND REPRODUCTIVE PERFORMANCE OF JAPANESE QUAILS IN FLOOR PENS AND CONVENTIONAL CAGES WITH DIFFERENT STOCKING DENSITIES
}

\author{
T. M. El-Sheikh' ${ }^{1}$ N. M. Essa ${ }^{2}$; A. A. A. Abdel-Kareem ${ }^{1}$; and M. A. Elsagheer ${ }^{2}$ \\ ${ }^{1}$ Poult. Prod. Dep., Fac. of Agric., Sohag Univ., Sohag, Egypt \\ ${ }^{2}$ Anim. and Poult. Prod. Dep., Fac. of Agric., Al-Azhar Univ., Assiut, Egypt \\ Corresponding author; Talaat Moustafa El-Sheikh, Email: talatm2@yahoo.com
}

\begin{tabular}{cc}
\hline Received:10/06/2016 & Accepted: 29/06/2016 \\
\hline
\end{tabular}

\begin{abstract}
This study was designed ( 2 x 3 ) to evaluate the effects of different housing systems; (floor pens and battery cages) and stocking density (20, 30 and 60 birds/m2) from 4-16 weeks of age on the productive, reproductive performance and egg quality of Japanese quail. A total number of 220 chicks sexed Japanese quail ( 72 males \& 148 females) at four weeks of age with $182 \mathrm{~g}$ average body weight were used. The chicks were randomly divided into two equal experimental groups according to housing systems (110 birds in each group which were 36 males and 74 females). The $1^{\text {st }}$ chicks group were housed on a partitions litter floor $(100 \times 50 \mathrm{~cm})$ provided with deep litter chopped wheat straw $(3 \mathrm{~cm})$, while the 2 nd chicks group were housed in battery cages $(100 \times 50 \times 40 \mathrm{~cm})$. Each group was randomly divided into three densities of 20,30 and 60 birds $/ \mathrm{m}^{2}$ with two replicates. The results showed highly significant differences $(\mathrm{p} \leq 0.05)$ between floor pens and battery cages on daily feed intake, FCR at (12-16 weeks of age), age and body weight at sexual maturity, egg surface area, fertility rate and hatchability percentage. Birds in low density of 20 birds $/ \mathrm{m}^{2}$ significantly $(\mathrm{p} \leq 0.05)$ increased all productive traits except the age at sexual maturity, and yolk percentage were significantly $(\mathrm{p} \leq 0.05)$ decreased. From these results, it could be concluded that housing system of litter floor pens had significant positive effects on the productive, reproductive traits and egg quality traits of Japanese quail as compared to battery cages. Also, quails at low density $\left(20 \mathrm{birds} / \mathrm{m}^{2}\right)$ had better performance than those at high density (30 and 60 birds/m2).
\end{abstract}

Key words: Housing systems- stocking densities- productive performance- egg quality 


\section{INTRODUCTION}

Japanese quail (Coturnix coturnix japonica) is considered one of the important alternative resources of animal protein, because it have many advantages such as fast growth, early sexual maturity, short incubation period, small size and high egg production, low feed requirements and its housing costs, less floor space compared with the different species of poultry (Mady, 1981; and Padmakumar et al., 2000). Also, quails are widely distributed in many countries of the world (Seker et al., 2009; Roshdy et al., 2010 and El-Tarabany et al., 2015).

Housing system is the most important factor affecting poultry production; therefore many researchers studied the effect of housing systems on behavioral, productive and reproductive traits of poultry (Roshdy et al., 2010). However, in developed countries about $90 \%$ of hens are kept in cages (Tauson, 1998). Quail hens preferred to lay their eggs in nests, the percentage of eggs found in nests was significantly higher than those on floor that was covered with plants and artificial shelters (Schmid and Wechsler, 1997). Laying hens kept in cages were significantly heavier than those kept in litter floor or free range systems (Van Loon et al., 2004).The findings of Alam et al. (2008) showed that egg production for quails reared in battery cages was higher than that reared on littered floor, while Arumugam et al. (2014) found that the fertility level for Japanese quails was not affected by system of rearing. Feed intake for hens reared in cages was lower compared to those on deep litter per kg egg mass (Oluyemi and Roberts, 1975; and Antic et al., 1985).

Stocking density in layers was inversely related with feed consumption (Teng et al., 1990), whereas feed conversion showed significant improvement with proportionate increase in cage space per layer in Japanese quails (Nagarajan et al., 1991). Several studies recommended using battery cages for keeping the adult Japanese quail, layers as well as breeders hens (Akram et al., 2000; and Alam et al., 2008). Similarly, the findings of Padmakumar et al. (2000) and Farghly (2008) showed that Japanese quail reared in battery cage had better body weight and egg weight than those raised on litter floor. In contrast, Roshdy et al. (2010) reported that floor pens housing system had significantly positive effects on the productive and reproductive performance of laying Japanese quail compared to battery cages. The results of Seker et al. (2009) indicated that increasing stocking density led to reduction egg production. Also, Attia et al. (2012) found that increasing stocking density of Japanese quail from 12 to 24 birds per 2000 $\mathrm{cm}^{2}$,resulting in reduction live body weight and body weight gain during 4-6 and 1-6 weeks of age.

The present study aimed to investigate the effect of housing systems and different stocking densities on the productive and reproductive performance traits of Japanese quail.

\section{MATERIALS AND METHODS}

This study was carried out at the Experimental Poultry Farm Animal production Department, Faculty of Agriculture, AL-Azhar University, Assiut Branch, Egypt.

Experimental Design

The experiment was a 2 × 3 factorial arrangement of treatments, consisting of two housing systems, three stocking densities with tow replicates for each. A total number of two hundred and twenty sexed Japanese quail at 4 weeks of age (72 males \& 148 females) were used in this experiment. All birds were wing banded, individually weighed and randomly 
divided into two equal groups. In the $1^{\text {st }}$ group, chicks were reared on a partitions litter floor $(100 \times 50 \mathrm{~cm})$ provided with deep litter chopped wheat straw $(3 \mathrm{~cm})$, while those in the $2^{\text {nd }}$ group were housed in battery cages $(100 \times 50 \times 40 \mathrm{~cm})$ with $1: 2$ sex ratios. Each group was divided into two subgroups of three densities $(10,15$ and $30 \mathrm{birds} / \mathrm{half}^{2}$ ) with two replicates. At 4 weeks of age ,all birds were exposed to the same lighting program which was (13L: 11D)with light intensity of 10 lux and increasing an hour per week up to (16L: 8D) at 8 weeks of age with 20 lux intensity. Feed and water were was available allover experimental period. Diet composition which used in this experiment is presented in Table (1).

Meteorological observations: The daily internal and external ambient temperatures $\left({ }^{\circ} \mathrm{C}\right)$ and relative humidity $(\%)$ were recorded at $12 \mathrm{AM}$ and $3 \mathrm{PM}$, respectively. The means of THI (units) were weekly and

Total egg number

$$
\begin{aligned}
& \text { HDP }(\%)=\frac{\text { Daily hen number }}{\text { Total egg number }} \times 100 \\
& \operatorname{HHP}(\%)=\frac{\text { Total egg number }}{\text { Initial number of hen's } \times \text { Day's number of season }} \times 100 \\
& \operatorname{SP}(\%)=\frac{\text { Final number of hen's } \times \text { Day's number of season }}{\text { Egg number }} \times 100 \\
& \text { Laying rate }(\%)=\frac{100}{\text { Hen number }}
\end{aligned}
$$

Egg quality traits: At 12 weeks of age, 200 fresh-laid eggs were collected throughout seven day and then used to measure egg quality characteristics ( 2 groups' $\times 100$ eggs). Egg weight (g) was daily recorded to the nearest $0.1 \mathrm{~g}$ on the same day of collection using special automatic balance. Both of egg length and width $(\mathrm{cm})$ were determined using a sliding caliper. Egg shape index was determined according to Reddy et al. (1979) as follow: Egg shape index $=($ Egg width $/$ Egg length $)$ x 100. every 4 weeks calculated according the formula of Marai et al. (2002) as follows: $\mathrm{THI}=\mathrm{db}{ }^{\circ} \mathrm{C}-\left[(0.31-0.31 \mathrm{RH})\left(\mathrm{db}^{\circ} \mathrm{C}-14.4\right)\right]$ where: $\mathrm{db}^{\circ} \mathrm{C}=$ dry bulb temperature in Celsius and RH = RH\% / 100.

The traits studied:

Feed intake and feed conversion ratio: Feed consumption was weekly recorded and FCR as $\mathrm{g}$ feed/g egg mass were calculated during the periods from 8 to 16 weeks of age, as follow: FCR=Feed intake $(\mathrm{g}) /$ weight of produced egg $(\mathrm{g})$.

Egg production traits: Age and body weight at sexual maturity were determined at $50 \%$ of females reached egg laying rate on group basis. The eggs were daily collected to calculate egg number every four weeks during $8^{\text {th }}$ to $16^{\text {th }}$ weeks of age. Eggs were weighed individually and recorded every day to calculate average egg weight (g) and egg mass ( $\mathrm{g}$ ). The egg production traits were calculated according to the follow equations every 4 weeks

Both of thick albumen and yolk height were measured using a Micrometer, as described by Brant and Shrader (1952). Yolk diameter was measured by using a sliding caliper. The yolk weight (g) was separated from the albumen and weighted, while shell with membranes were dried at 72 hours and weighed to the nearest 0.01 g. Yolk index was calculated as follow: Yolk index $=($ Yolk height $/$ yolk diameter $)$ $\times 100$. 
Shell thickness of the dried shell (without membranes) was measured using shell thickness apparatus minus at four different regions of the shell (blunt, pointed and both sides) and the average was recorded (millimeters).The albumen weight ( $\mathrm{g}$ ) was calculated by subtracting egg weight from both of shell and yolk weight. The three egg components were expressed as percentages of the egg weight.

Fertility and hatchability percentages: At $11^{\text {th }}$ week of age, eggs were collected and stored 7 days at $15-18^{\circ} \mathrm{C}$ and $70-75 \% \mathrm{RH}$ before incubation. The incubation was performed by using automatic Paterzime setter and Hatcher under the recommended temperature $\left({ }^{\circ} \mathrm{C}\right), \mathrm{RH}(\%)$, ventilation and turning for incubated eggs. Hatchability (\%) was calculated as follow:

Hatchability $=$ Fertile eggs $\times 100 /$ Total set eggs.

Statistical analysis:

The achieved Data were subjected to a two-ways analysis of variance with treatment group effect by using the GLM procedure of SAS (1998) according to the following model: $\mathrm{Yijk}=\mu+\mathrm{Hi}+\mathrm{Sj}+\mathrm{HSij}$ + eijk

Where, Yijk = an observation;

$\mu=$ general mean;

$\mathrm{Hi}=$ fixed effect of $\mathrm{i}^{\text {th }}$ Housing system, $\mathrm{i}=$ 1 \& 2 (Battery or Litter floor);

$\mathrm{Sj}=$ fixed effect of $\mathrm{jth}$ stocking density, $\mathrm{i}=$ 1,2 and 3 (Low, mid and high);

$\mathrm{HSij}=$ interaction effect of $\mathrm{i}^{\text {th }}$ Housing system and $\mathrm{j}^{\text {th }}$ stocking density and

eijk $=$ error of the model, which included all the other effects not specified in the mixed model.

Differences among experimental groups were separated by Duncan's multiple range test (Duncan, 1955). The rate values of fertility and HDP (\%) were transformed to Arcsine values before analysis.

\section{RESULTS AND DISCUSSIONS}

Feed intake and feed conversion ratio

The results in Table 3 indicated that birds raised on litter floor had significantly higher $(p \leq 0.05)$ feed intake than those in cages. The decrease in feed intake for quails raised in battery cages could be attributed to the decrease in movement and physiological body status or due to the fact that birds in cages were not free as compared to those on floor (Bilal et al, 2014; and Olawumi Simeon, 2015). These results are in agreement with those of Abdel-Magied (2006), who concluded that the daily feed intake was higher for Japanese quail raised on litter floor than those in the battery cages during 11-21 weeks of age.

Data presented in Table 3, shows that no significant effect on feed conversion ratio during production period except during (12-16) weeks of age where the birds in battery cages had significant better $(p \leq 0.05)$ feed efficiency than those in litter floor. The improvement of feed conversion ratio in cages could be attributed to increase egg number during the period (1216) and decrease feed intake in cages than floor. These results are in agreement with those of Sharaf (1996) and Abdel-Magied (2006), whom reported that the feed efficiency for Japanese quail housed in battery cage was higher than birds housed on the litter floor. However, Padmakumar et al. (2000) revealed that the average feed efficiency for Japanese quails in battery cage and litter floor from 5 to 50 weeks of age was not affected.

Effect of stocking density, data presented in Table 3, shows that Japanese quails kept at low density consumed significantly $(p \leq 0.05)$ more feed as compared with those kept at high density. This decrease in feed consumption for quails kept at high density could be attributed to the increase bids per cage, increase in heat stress and ammonia as well as decrease in feeder and watering spaces, which led to increasing the competition to consume more feed consumption (Mtileni et al., 2007). These results are in agreement with those of Abdel-Magied (2006) showed that feed 
intake for Japanese quail increased significantly $(p \leq 0.05)$ with increasing cage floor space per bird from 11 to 21 weeks of age.

Data presented in Table 3, shows that quails which raised under lower density had a better $(p \leq 0.05)$ feed conversion ratio during production period. The improvement of feed conversion ratio may be due to increase of egg number and egg weight which produced by quails at low density. These results are in agreement with those of Akram et al. (2000), Fahmy and El-Faramawy (2004), Abdel-Magied (2006) and Attia et al. (2012); they reported that the feed conversion ratio in Japanese quail decreased significantly $(\mathrm{p} \leq 0.05)$ with increasing the number of birds per square meter during production period. However, Santos et al. (2011) found that feed conversion ratio of Japanese quail was better in the group of 9 birds/ cage than that 3 or 6 birds/cage.

The effect of interaction on daily feed intake was significantly $(p \leq 0.05)$, but there was no significant effect on feed conversion ratio. These differences in daily feed intake may be attributed to the effect of housing system as well as stocking density on quail performance.

\section{Egg production}

Effect of housing systems, data presented in Table 4, shows that the females raised on litter floor had significantly higher $(\mathrm{p} \leq 0.05)$ body weight $(220.77 \mathrm{~g})$ and earlier age (56.50 days) at sexual maturity than those kept in battery cages. This improves in body weight and age at sexual maturity for Japanese quails raised on litter floor could be attributed to improve in viability, physiological body status as well as rearing condition than those of quails reared in battery cages. These results are disagreement with those of Padmakumar et al. (2000) who showed that the age at sexual maturity of Japanese quail raised in battery cage was earlier than those raised on litter floor. However, Farghly (2008) indicated that the average of age and body weight at sexual maturity amounted 44.2 days and $179.8 \mathrm{~g}$ for female Japanese quail raised in cages than those raised on litter floor which was 45.0 days and $175.5 \mathrm{~g}$, without any significant differences.

Data presented in Table 4, shows that different housing system had no significant effects on egg weight, egg number, egg mass, hen day egg production, hen housed egg production, survival production and laying rate. These results are in agreement with those of Padmakumar et al. (2000) who found that housing system did not affect the egg production in Japanese quail at 5-50 weeks of age. However, Christmas et al. (1972) found higher egg production in quails which reared on litter floor than those in cages. While, Gandhimathi et al. (2014) found that egg production of Japanese quail was $80 \%$ in cage system and $70 \%$ in deep litter system.

Effect of stocking density, data presented in Table 4, shows that the females kept at high density had lower $(\mathrm{p} \leq 0.001)$ body weight (210.54g) and late age (62 day) at sexual maturity than those at low density. This improvement in body weight and age at sexual maturity could be attributed to decrease in the competition to obtain feed intake and increase bird's welfare than those at high density (Faitarone et al., 2005). These results are in agreement with those of Tozluca (1993), who indicated that quails kept in high stocking density had late sexual maturity.

Results indicated that the means egg weight, egg number, egg mass, hen day egg production, hen housed egg production and laying rate decreased significantly $(\mathrm{p} \leq 0.05)$ with increasing birds density in cages. The higher stress and lower feed intake as well as the late age at sexual maturity may be responsible for the lower egg production traits at high density (Faitarone et al., 2005). These results are in agreement with those of Dhaliwal et al. (2007), whom reported that the Japanese quails housed at low density (66.66 birds $\left./ \mathrm{m}^{2}\right)$ produced the highest $(\mathrm{p} \leq 0.05)$ 
number of eggs than those at high density (83.33 birds $\left./ \mathrm{m}^{2}\right)$. Also, Abdel-Magied (2006) showed that hen-day egg production and egg weight in Japanese quail increased significantly $(p \leq 0.05)$ with increasing the space of floor cage at 11-21 weeks of age.

The effect of interaction on age at sexual maturity was significantly $(p \leq 0.05)$, but there wereno significant effect on body weight at sexual maturity, egg weight, egg number, egg mass, $\mathrm{HDP} \%, \mathrm{HHP} \%, \mathrm{SP} \%$ and $\mathrm{LR} \%$.

\section{Egg quality traits}

Effect of housing systems, data in Tables5, shows that there was insignificantly effect of housing system (cage vs. floor) on egg shape, shell percentage, shell thickness with or without membranes, yolk index, yolk percentage, albumen percentage and Haugh unit. However, eggs laid on litter floor had higher $(\mathrm{p} \leq 0.05)$ egg surface area than those laid in battery cages. This increase in egg surface area for Japanese quails raised on litter floor could be attributed to increase in egg weight than those in battery cages. These results are in agreement with those of Padmakumar et al. (2000) who showed that the shape index, shell thickness, yolk index and Haugh unit were not affected by the housing system for Japanese quails. Abdel-Fatah (2008) found that housing system (deep-litter \& battery) had no significant effect on internal egg quality in Japanese quail during the first laying period. In contrast, Alam et al. (2008) found that the averages of shape index and shell thickness for Japanese quail were better in battery cage than those of the birds kept under litter floor at 24-30 weeks of age.

Regarding the effect of stocking density, data in Tables5, showed that females kept at low density laid eggs had higher $(p \leq 0.05)$ shell thickness with or without membranes and egg surface area as compared to those at high density. While, the yolk percentage was higher $(p \leq 0.05)$ in eggs which laid by quails at high stocking density than those at low density. On the other hand, there no significant effects on egg shape, shell percentage, yolk index, albumen percentage and Haugh unit. This increase in shell thickness with or without membranes and egg surface area for Japanese quails raised at lower stocking density could be attributed to increase in egg weight, shell weight and absence heat stress than those at high stocking density. Also, the increase in yolk percentage at high density could be attributed to decrease of egg weight at high density. These results are in agreement with those of Bandyopadhay and Ahuja (1990), whom reported that cage density had no effect on shape index and albumen index in egg of Japanese quail at 20 weeks of age. El-Tarabany et al. (2015) indicated that the Japanese quails housed at low density $\left(200 \quad \mathrm{~cm}^{2}\right.$ /bird $)$ increased significantly $(\mathrm{p} \leq 0.05)$ for eggshell weight, shell percentage and shell thickness than those at higher cage floor density (167 and $143 \mathrm{~cm}^{2} /$ bird) at $14^{\text {th }}$ week of age. Padmakumar et al. (2000) showed that the average Haugh unit and egg yolk index for Japanese quail at deferent densities in cages and deep litter floor were not significant affected at $50^{\text {th }}$ week of age.

Regarding the effect of interaction $(\mathrm{HS} \times \mathrm{SD})$; the findings in Tables 5 showed no significant effects of interaction $(\mathrm{HS} \times \mathrm{SD})$ on external and internal egg quality traits except shell thickness with or without membranes. These differences may be attributed to effects of stocking density on birds.

\section{Fertility and hatchability}

The results in Table 6 , showed that the fertility rate and hatchability percentage were significantly higher $(p \leq 0.05)$ for eggs produced from quails reared on litter floor than those in battery cages, while the absolute and relative chick weights were not affected. The increased fertility rate may be attributed to increased viability and absence of leg and peak abnormalities which are essential for successful mating 
behavior as well as pecking percentage in quails which raised on litter floor than in battery cages. Also, the decreased hatchability in battery cages may be attributed to decreasing the fertile egg, which coincided with lower yolk index and shell thickness than fertile eggs produced from floor pens (Farooq et al., 2001; Meizar et al., 2008; and Karousa et al., 2015). These results agree with those of Karousa et al. (2015) indicated that the fertility rate showed the best results in quails of floor pens system than battery cages. In contrast, the findings of Sharaf (1996) indicated that quails reared on the litter floor had significantly lower fertility and hatchability than those raised on cages, which amounted 85.39 and $80.82 \%$ on cages and the corresponding figures on the floor were 73.66 and $57.66 \%$, respectively.

Regardless the effect of housing systems and the interaction $(\mathrm{HS} \times \mathrm{SD})$, the results in Table 6 , shows that the percentages of fertility and hatchability rates as well as absolute chick weight at hatching decreased significantly $(p \leq 0.05)$ with decreasing floor space per bird. But there was no significant effect on percentage chick weight at hatching. The decreasing fertility rate for eggs produced from quails at high density could be attributed to decrease feed intake, cannibalism as well as the competition among birds, the decrease of fertility led to low hatchability. These results are in agreement with those of Abdel-Magied (2006), who showed that the fertility and hatchability percentages for Japanese quail increased with increasing cage floor space at 11-21 weeks of age. While, Askar et al. (2012) reported that stocking density had not significant effects on fertility and hatchability rates for Japanese quails during the period from 10 to 18 weeks.

Regarding the effect of interaction $(\mathrm{HS} \times \mathrm{SD})$, the results showed no significant effects of interaction on quail fertility, hatchability as well as absolute and relative chick weights.

\section{CONCLUSION}

Generally, these results could be noted that there were significant differences $(p \leq 0.05)$ were found between housing systems on the most studied traits, Therefore, could be concluded that raising Japanese quails in battery cages had significant negative effects on most productive, reproductive and egg quality traits compared to floor pens. Also, quails at low density (20 birds $\left./ \mathrm{m}^{2}\right)$ had better performance than those at high density (30 and $60 \mathrm{birds} / \mathrm{m}^{2}$ ). In this respect, litter floor pens system could be recommended to increase Japanese quail breeder's performance especially at lower density (20 birds $/ \mathrm{m}^{2}$ ) under Upper Egypt climatic conditions. 
Table (1): Composition and calculation analysis of experimental diets of Japanese quails.

\begin{tabular}{|l|c|c|}
\hline \multicolumn{1}{|c|}{ Ingredients } & Starter (\%) & Layer (\%) \\
\hline Yellow corn (8.8\%) & 54.0 & 54.5 \\
Soybean meal (44\%) & 34.5 & 31 \\
Concentrate & $11.0^{*}$ & $8 * *$ \\
Salt & 0.3 & 0.50 \\
Dicalcium phosphate & 0.2 & 1.50 \\
Limestone & --- & 4.5 \\
Total & 100 & 100 \\
\hline Calculated Analysis:*** & \multicolumn{2}{|l}{} \\
\hline Crude Protein (\%) & 25.6 & 22.5 \\
ME ( KCal/ Kg diet) & 2840 & 2710 \\
Calcium (\%) & 0.92 & 2.77 \\
Available phosphorus (\%) & 0.5 & 0.87 \\
\hline
\end{tabular}

* Broiler concentrate contained: Crude protein, 52\%; Crude fiber, $1.6 \%$; Ether extract, 6.1\%; Calcium, 7\%; Available phosphorus, 3.5\%; Methionine, 1.5\%; Methionine and Cystine, 2.1\%; Lysine, 3\%; and Metabolizable energy, $2416 \mathrm{kcal} / \mathrm{kg}$ diet.

$* *$ The layer concentrate contained: Crude protein, $51 \%$; Lysine, $3.3 \%$; Crude fiber, 2.0\%; Calcium, 8.0\%; Crude fat, $6.4 \%$; Available phosphorus, 3.0\%; Methionine, $1.67 \%$; Salt, 3.19\%; Methionine + Cystine, $2.25 \%$; and Metabolizable energy, $2400 \mathrm{kcal} / \mathrm{diet}$. *** Calculated according to NRC (1994).

Table(2): Exterior and interior temperature (T), relative humidity (RH) and temperature humidity index (THI) allover experimental period.

\begin{tabular}{|c|c|c|c|c|c|c|c|c|c|}
\hline \multirow[b]{2}{*}{$\overbrace{}^{\frac{y}{ \pm}}$} & \multirow{2}{*}{ 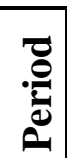 } & \multirow[b]{2}{*}{ Season } & \multicolumn{3}{|c|}{ Exterior } & \multicolumn{3}{|c|}{ Interior } & \multirow{2}{*}{$\begin{array}{l}\text { THI } \\
\text { Ext-In } \\
\text { (units) }\end{array}$} \\
\hline & & & $\begin{array}{l}\text { AT } \\
\left({ }^{\circ} \mathrm{C}\right)\end{array}$ & RH (\%) & $\begin{array}{c}\text { THI } \\
\text { (units) }\end{array}$ & $\begin{array}{l}\text { AT } \\
\left({ }^{\circ} \mathrm{C}\right)\end{array}$ & $\begin{array}{l}\text { RH } \\
(\%)\end{array}$ & $\begin{array}{l}\text { THI } \\
\text { (units) }\end{array}$ & \\
\hline 1 & & winter & 26.42 & 53.28 & 24.67 & 22.85 & 55.57 & 21.69 & 2.98 \\
\hline 2 & 1 & winter & 29.85 & 54.07 & 27.62 & 25.28 & 56.42 & 23.77 & 3.84 \\
\hline 3 & & winter & 29.42 & 54.42 & 27.31 & 24.85 & 57.50 & 23.48 & 3.82 \\
\hline 4 & & winter & 31.14 & 54.64 & 28.78 & 27.00 & 57.00 & 25.31 & 3.47 \\
\hline 5 & & Spring & 34.85 & 56.28 & 32.07 & 28.14 & 58.14 & 26.34 & 5.73 \\
\hline 6 & 2 & Spring & 32.14 & 58.28 & 29.85 & 26.85 & 60.92 & 25.35 & 4.50 \\
\hline 7 & & Spring & 32.85 & 56.42 & 30.35 & 28.71 & 58.85 & 26.88 & 3.46 \\
\hline 8 & & Spring & 36.57 & 57.42 & $\beta 3.66$ & 31.28 & 59.64 & 29.16 & 4.50 \\
\hline 9 & & Spring & 41.42 & 53.85 & 37.56 & 33.57 & 56.07 & 30.95 & 6.61 \\
\hline 10 & 3 & Spring & 38.00 & 48.00 & 34.18 & 32.28 & 50.42 & 29.53 & 4.65 \\
\hline 11 & & Spring & 33.42 & 53.42 & 30.69 & 28.00 & 57.21 & 26.20 & 4.48 \\
\hline 12 & & Spring & 35.42 & 57.28 & 32.66 & 30.57 & 60.21 & 28.59 & 4.07 \\
\hline
\end{tabular}

$\mathrm{AT}=$ Ambient temperature $\left({ }^{\circ} \mathrm{C}\right), \mathrm{RH}=$ Relative humidity $(\%)$ and $\mathrm{THI}=$ Temperature humidity index (units) 
Table( 3): Daily feed intake (g) and feed conversion ratio ( $\mathrm{g}$ feed/ $\mathrm{g}$ egg) of Japanese quails affected by housing systems, stocking density and their interaction.

\begin{tabular}{|c|c|c|c|c|}
\hline \multirow{2}{*}{$\begin{array}{c}\text { Housing system } \\
\text { Stocking density } \\
\text { traits }\end{array}$} & \multirow{2}{*}{$\begin{array}{c}\text { Daily } \\
\text { feed intake (g) }\end{array}$} & \multicolumn{3}{|c|}{ Feed conversion ratio ( $\mathrm{g}$ feed/ g egg) } \\
\hline & & 8-12 week & 12-16 week & 8-16 week \\
\hline \multicolumn{5}{|c|}{ Effect of treatment } \\
\hline Battery & $31.8^{\mathrm{b}} \pm 1.9$ & $23.37^{\mathrm{a}} \pm 5.5$ & $14.13^{\mathrm{a}} \pm 3.1$ & $18.75^{\mathrm{a}} \pm 5.7$ \\
\hline Litter & $36.1^{\mathrm{a}} \pm 3.1$ & $23.16^{\mathrm{a}} \pm 5.4$ & $17.64^{\mathrm{b}} \pm 3.9$ & $20.01^{\mathrm{a}} \pm 4.5$ \\
\hline \multicolumn{5}{|c|}{ Effect of Density } \\
\hline D1 & $40.6^{\mathrm{a}} \pm 2.1$ & $8.78^{\mathrm{c}} \pm 0.9$ & $8.77^{\mathrm{c}} \pm 0.3$ & $8.73^{c} \pm 0.6$ \\
\hline D2 & $34.4^{\mathrm{b}} \pm 1.5$ & $18.29^{\mathrm{b}} \pm 1.8$ & $11.99^{\mathrm{b}} \pm 1.2$ & $15.12^{\mathrm{b}} \pm 1.3$ \\
\hline D3 & $26.9^{\mathrm{c}} \pm 0.2$ & $42.72^{\mathrm{a}} \pm 4.0$ & $26.90^{\mathrm{a}} \pm 1.6$ & $34.81^{\mathrm{a}} \pm 2.8$ \\
\hline \multicolumn{5}{|c|}{ Effect of interaction } \\
\hline Battery*D1 & $37.1^{\mathrm{AB}} \pm 0.5$ & $7.55 \pm 2.1$ & $8.40 \pm 1.1$ & $7.92 \pm 1.6$ \\
\hline Battery*D2 & $31.7^{\mathrm{BC}} \pm 0.6$ & $15.73 \pm 3.8$ & $9.95 \pm 0.4$ & $12.82 \pm 1.1$ \\
\hline Battery*D3 & $26.6^{\mathrm{C}} \pm 0.0$ & $47.50 \pm 2.3$ & $24.05 \pm 0.1$ & $36.00 \pm 1.1$ \\
\hline Litter*D1 & $44.1^{\mathrm{A}} \pm 2.4$ & $8.01 \pm 0.9$ & $9.03 \pm 0.2$ & $8.53 \pm 0.3$ \\
\hline Litter*D2 & $37.1^{\mathrm{AB}} \pm 0.0$ & $16.84 \pm 0.9$ & $11.03 \pm 1.1$ & $13.89 \pm 1.0$ \\
\hline Litter*D3 & $27.2^{\mathrm{C}} \pm 0.0$ & $48.63 \pm 3.9$ & $25.75 \pm 1.0$ & $37.16 \pm 2.4$ \\
\hline \multicolumn{5}{|c|}{ Probability } \\
\hline Housing & $* * *$ & $\mathrm{NS}$ & $* *$ & $\mathrm{NS}$ \\
\hline density & $* * *$ & $* * *$ & $* * *$ & $* * *$ \\
\hline Housing $\mathrm{x}$ density & $*$ & NS & NS & NS \\
\hline
\end{tabular}

$a, b, c$ Means with different superscripts in the same column for each effect are significantly different $(\mathrm{p}<0.05)$. 
Table (4): Egg production traits of Japanese quails affected by housing systems, stocking density and their interaction.

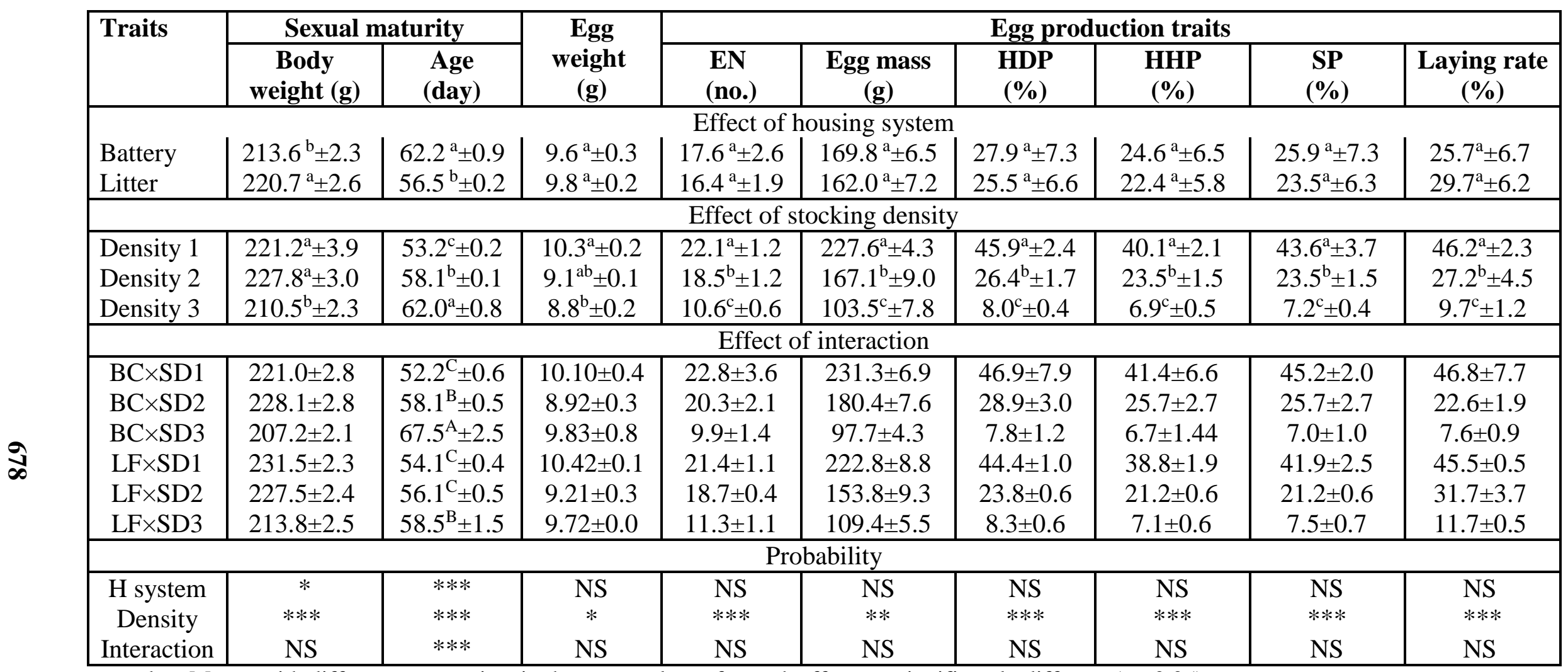

a, b, c Means with different superscripts in the same column for each effect are significantly different $(\mathrm{p}<0.05)$.

HHP: Hen housed production, LR: Layer rate, SP: Survival production, EPW: Egg production weight, TEN: Total egg number, DEN: Daily egg number, HDP: Hen day egg production. 
Table (5): Egg quality traits affected by housing system, stocking density and their interaction.

\begin{tabular}{|c|c|c|c|c|c|c|c|c|c|}
\hline $\begin{array}{c}\text { Housing } \\
\text { system } \\
\text { Stocking } \\
\text { density } \\
\text { traits }\end{array}$ & $\begin{array}{c}\text { Egg } \\
\text { shape }\end{array}$ & Shell \% & $\begin{array}{c}\text { Shell } \\
\text { Thickness }\end{array}$ & $\begin{array}{c}\text { Shell } \\
\text { without } \\
\text { membranes }\end{array}$ & $\begin{array}{c}\text { Egg } \\
\text { surface } \\
\text { area }\end{array}$ & $\begin{array}{c}\text { Yolk } \\
\%\end{array}$ & $\underset{\%}{\text { Albumen }}$ & $\begin{array}{c}\text { Yolk } \\
\text { index }\end{array}$ & Haugh unit \\
\hline \multicolumn{10}{|c|}{ Effect of housing system } \\
\hline Battery cage & $0.78^{\mathrm{a}} \pm 0.0$ & $8.20^{\mathrm{a}} \pm 0.1$ & $0.19^{\mathrm{a}} \pm 0.0$ & $0.17^{\mathrm{a}} \pm 0.0$ & $19.22^{\mathrm{b}} \pm 0.2$ & $34.99^{\mathrm{a}} \pm 0.3$ & $56.80^{\mathrm{a}} \pm .3$ & $1.99^{\mathrm{a}} \pm 0.0$ & $96.72^{\mathrm{a}} \pm 1.0$ \\
\hline Litter floor & $0.78^{\mathrm{a}} \pm 0.0$ & $7.89^{\mathrm{a}} \pm 0.1$ & $0.19^{\mathrm{a}} \pm 0.0$ & $0.17^{\mathrm{a}} \pm 0.0$ & $20.09^{\mathrm{a}} \pm 0.2$ & $35.27^{\mathrm{a}} \pm 0.3$ & $56.82^{\mathrm{a}} \pm 0.3$ & $1.96^{\mathrm{a}} \pm 0.0$ & $97.18^{\mathrm{a}} \pm 0.3$ \\
\hline Density 2 & $0.78^{\mathrm{ab}} \pm 0.0$ & $8.27^{\mathrm{a}} \pm 0.2$ & $0.19^{\mathrm{b}} \pm 0.0$ & $0.17^{\mathrm{b}} \pm 0.0$ & $20.15^{\mathrm{a}} \pm 0.2$ & $34.84^{\mathrm{b}} \pm 0.4$ & $56.88^{\mathrm{a}} \pm 0.3$ & $1.95^{\mathrm{a}} \pm 0.0$ & $96.99^{\mathrm{a}} \pm 1.0$ \\
\hline Density 3 & $0.77^{\mathrm{a}} \pm 0.0$ & $7.81^{\mathrm{a}} \pm 0.2$ & $0.17^{\mathrm{c}} \pm 0.0$ & $0.15^{\mathrm{c}} \pm 0.0$ & $\begin{array}{r}19.10 \\
\mathrm{~b}_{ \pm 0.2} \\
\end{array}$ & $35.99^{\mathrm{a}} \pm 0.4$ & $56.20^{\mathrm{a}} \pm 0.4$ & $1.98^{\mathrm{a}} \pm 0.0$ & $96.49^{\mathrm{a}} \pm 0.8$ \\
\hline \multicolumn{10}{|c|}{ Effect of interaction } \\
\hline $\mathrm{BC} \times \mathrm{SD} 1$ & $0.78 \pm 0.0$ & $7.96 \pm 1.4$ & $021^{\mathrm{A}} \pm 0.0$ & $0.19^{\mathrm{A}} \pm 0.0$ & $19.40 \pm 1.7$ & $34.62 \pm 3.1$ & $57.40 \pm 3.4$ & $1.98 \pm 0.4$ & $97.31 \pm 0.6$ \\
\hline $\mathrm{BC} \times \mathrm{SD} 2$ & $0.79 \pm 0.0$ & $8.45 \pm 1.5$ & $0.18^{\mathrm{C}} \pm 0.0$ & $0.16^{\mathrm{BC}} \pm 0.0$ & $19.68 \pm 1.6$ & $34.12 \pm 2.5$ & $57.41 \pm 2.9$ & $1.98 \pm 0.1$ & $96.53 \pm 2.0$ \\
\hline \multicolumn{10}{|c|}{ Probability } \\
\hline H system & NS & NS & NS & NS & $* * *$ & NS & NS & NS & NS \\
\hline Density & NS & NS & $* * *$ & $* * *$ & $* *$ & $*$ & NS & NS & NS \\
\hline Interaction & NS & NS & $* * *$ & $* *$ & NS & NS & NS & NS & NS \\
\hline
\end{tabular}

a, b, c Means with different superscripts in the same column for each effect are significantly different $(\mathrm{p}<0.05)$. $\mathrm{BC}=$ Battery cages and $\mathrm{LF}=\mathrm{Litter}$ floor. 
Table(6): Effect of housing system and stocking density on Fertility and hatchability percentages.

\begin{tabular}{|c|c|c|c|c|}
\hline \multirow{2}{*}{$\begin{array}{c}\text { Housing system } \\
\text { Stocking density } \\
\text { traits }\end{array}$} & \multirow{2}{*}{$\begin{array}{c}\text { Fertility } \\
(\%)\end{array}$} & \multirow{2}{*}{$\begin{array}{c}\text { Hatchability } \\
(\%)\end{array}$} & \multicolumn{2}{|c|}{ Chick weight } \\
\hline & & & Absolute & $(\%)$ \\
\hline \multicolumn{5}{|c|}{ Effect of housing system } \\
\hline Battery cage & $65.58^{\mathrm{b}} \pm 2.9$ & $39.78^{\mathrm{b}} \pm 2.1$ & $6.48^{\mathrm{a}} \pm 0.1$ & $64.95^{\mathrm{a}} \pm 5.1$ \\
\hline Litter floor & $68.70^{\mathrm{a}} \pm 4.0$ & $47.40^{\mathrm{a}} \pm 1.7$ & $6.61^{\mathrm{a}} \pm 0.2$ & $66.20^{\mathrm{a}} \pm 1.2$ \\
\hline \multicolumn{5}{|c|}{ Effect of stocking density } \\
\hline Density 1 & $75.08^{\mathrm{a}} \pm 2.4$ & $47.47^{\mathrm{a}} \pm 1.5$ & $6.88^{\mathrm{a}} \pm 0.1$ & $67.27^{\mathrm{a}} \pm 1.4$ \\
\hline Density 2 & $69.30^{\mathrm{b}} \pm 1.2$ & $44.00^{\mathrm{a}} \pm 2.4$ & $6.55^{\mathrm{ab}} \pm 0.1$ & $62.99^{\mathrm{ab}} \pm 7.1$ \\
\hline Density 3 & $56.11^{\mathrm{c}} \pm 1.0$ & $38.25^{\mathrm{b}} \pm 3.4$ & $6.18^{\mathrm{b}} \pm 0.1$ & $57.46^{\mathrm{b}} \pm 3.6$ \\
\hline \multicolumn{5}{|c|}{ Effect of interaction } \\
\hline $\mathrm{BC} \times \mathrm{D} 1$ & $71.28 \pm 2.9$ & $44.94 \pm 0.7$ & $6.87 \pm 0.1$ & $67.85 \pm 2.8$ \\
\hline $\mathrm{BC} \times \mathrm{D} 2$ & $69.01 \pm 2.4$ & $46.00 \pm 0.0$ & $6.42 \pm 0.1$ & $50.14 \pm 1.7$ \\
\hline $\mathrm{BC} \times \mathrm{D} 3$ & $54.70 \pm 1.2$ & $37.28 \pm 2.1$ & $6.17 \pm 0.2$ & $56.27 \pm 2.1$ \\
\hline $\mathrm{LF} \times \mathrm{D} 1$ & $78.88 \pm 1.6$ & $50.0 \pm 0.0$ & $6.89 \pm 0.4$ & $66.68 \pm 3.8$ \\
\hline $\mathrm{LF} \times \mathrm{D} 2$ & $69.69 \pm 4.3$ & $50.0 \pm 0.0$ & $6.73 \pm 0.4$ & $67.27 \pm 3.7$ \\
\hline $\mathrm{LF} \times \mathrm{D} 3$ & $57.53 \pm 1.2$ & $42.22 \pm 3.1$ & $6.20 \pm 0.3$ & $64.64 \pm 4.4$ \\
\hline \multicolumn{5}{|c|}{ Probability } \\
\hline Housing & $*$ & $*$ & NS & NS \\
\hline density & $* * *$ & $* * *$ & $*$ & $*$ \\
\hline $\mathrm{HS} \times \mathrm{SD}$ & NS & NS & NS & $\mathrm{NS}$ \\
\hline
\end{tabular}

$\mathrm{a}, \mathrm{b}, \mathrm{c}$ Means with different superscripts in the same column for each effect are significantly different $(\mathrm{p}<0.05)$.

$\mathrm{BC}=$ Battery cages and $\mathrm{LF}=$ Litter floor.

\section{REFERENCES}

Abdel-Fatah, E. M. M., 2008. Study on effect of some managerial factors on behavior and performance of quail. M.S. Thesis, Fac. Vet. Med., Benha University, Egypt.

Abdel-Magied, S. M. S., 2006. Studies on some factors affecting productive performance and fertility of Japanese quail (Coturnix coturnix japonica). M.S. Thesis, Faculty of Agriculture, Al-Azher University, Egypt.

Akram, M.; Shah, H.; and khan, M. I., 2000. Effect of varying floor space on productive performance of Japanese quail breeders maintained under litter floor and cage housing systems. Pak. J. Agric. Sci., 37(1-2): 42-46.

Alam, M. S.; Abdur Rahman, M. H.; Mondal, A.; Hossain, K.; and
Bostami, A. B. M. R., 2008. Pattern of egg production in Japanese quail reared on littered floor and in cage. Bang. Res. Public. J., 1(3): 239-249.

Antic, D.; Gajic, D.; and Masic, B., 1985. The effect of housing on the performance of broiler parental flocks. Peradarstvo, 20(12): 27-29.

Arumugam, R.; Prabakaran, R.; and Silvakumar, T., 2014. Hatching performance of pure bred Japanese quail breeders under cage and deep litter systems of rearing. J. Global Bio. Sci., 3(7): 1105-1110.

Askar, A. A.; El-Hindawy, M. M.; Soliman, M. M; and Al-Hanafy, L. A., 2012. Some physiological traits of laying Japanese quails as affected by sodium bicarbonate and ascorbic acid under two stocking densities. Egypt. Poult. Sci. J., 32: 5-11. 
Attia, A. I.; Mahrose, Kh. M.; Ismail, I. E.; and Abdul-kasem, D. E., 2012. Response of growing Japanese quail raised under two stocking densities to dietary protein and energy levels. Egypt. J. Anim. Prod., 47: 159-166.

Bandyopadhay, U. K.; and Ahuja, S. D., 1990. Effect of cage density on some of the performance traits in Japanese quail. Ind. J. Poult. Sci., 25(2): 123-128.

Bilal, K.; Mehmood, S.; Akram, M.; Imran, S.; Sahota, A. W.; Javed, K.; Hussain, J.; and Ashfaq, H., 2014. Growth performance of broilers under two rearing systems in three different housing zones in an environmentally controlled house during winter. J. Anim. Plant Sci., 24(4): 1039-1044.

Brant, A. W.; and Shrader, H. L., 1952. How to measure internal egg quality? Bureau of Animal Industry. Agric. Res. Administration, U.S. Dept. of Agric., Circular P. A. 202.

Christmas, R. B.; O'Steen, A. W.; Douglas, C. R.; Kalch L. W.; and Harms, R. H. 1972. A study of strain interaction of cage versus floor layers for three evaluation periods of the Florida Poultry Evaluation Center. Poult. Sci., 51(5): 1794-1795.

Duncan, D. B., 1955. Multiple range and multiple F test. Biometrics 11:1-42.

Dhaliwal, A. P. S.; Nagra, S. S.; and Brah, G. S., 2007. Effect of cage stocking density and season on laying performance of Japanese quail (coturnix coturnix japonica). Ind. J. Poult. Sci., 42(3): 243-247.

El-Tarabany, M. S.; Abdel-Hamid, T. M.; and Mohammed, H. H., 2015. Effect of cagestocking density on egg quality traits in Japanese quail. Kafkas Univ. Vet. Fak. Derg., 21(1): 13-18.

Fahmy, M. O.; and El-Faramawy, A. A., 2004. Japanese quail performance under different stocking densities. Isotope Rad. Res., 36(3): 549-559.
Faitarone, A. B. G.; Pavan, A. C.; Mori, C.; Batista, L. S.; Oliveira, R. P.; Garcia, E. A.; Pizzolante, C. C.; Mendes, A. A.; and Sherer, M. R., 2005. Economic traits and performance of Italian quails reared at different cage stocking densities. Rev. Bras. Cienc. Avic., 7(1): 19-22.

Farghly, M. F. A., 2008. Improvement of poultry production through some recent managerial manipulations in Assiut. Ph.D. Thesis, Faculty of Agriculture, Assiut University, Egypt.

Farooq, M.; Aneela, K. ; Durrani, F. R.; Muqarrab, A. K.; Chand, N.; and Khurshid, A., 2001. Egg and shell weight, hatching and production performance of Japanese broiler quails. Sarhad J. Agric., 17: 289-293.

Gandhimathi, A.; Babu, M.; Asha rajini, R.; Sujatha, S.; Lurthu Reetha, T., 2014. Effect of nest box on the reproductive performance of Japanese quail. J. Int. Acad. Res. Multidisciplin., 2: (5).

Karousa, M. M.; Ahmed, S. A.; Elaithy, S. M.; and Elgazar, E. A., 2015. Effect of housing system and sex ratio of quails on egg production, fertility and hatchability. Benha vet. Medi. J, 28(2): 241-247.

Mady, M. E., 1981. Some factors affecting reproductive efficiency and productivity of Japanese quail under Egyptian environmental conditions. M.Sc. Thesis, Faculty of Agriculture, Ain Shams University, Egypt.

Marai, I. F. M.; Habeeb, A. A. M.; and Gad, A. E., 2002. Rabbits productive, reproductive and physiological performance traits as affected by heat stress: a review. Livest. Prod. Sci., 78: 71-90.

Meizar, E. M.; Karousa, M. M.; Elgendi, G. M.; Ahmed, S. A.; and Mahmoud, E. A., 2008. Study on effect of some managerial factors on behavior and performance of quail. M.Sc. Department 
of Animal Hygiene, Behavior and Management, Faculty of Veterinary Medicine, Benha University. Egypt.

Mtileni, B. J.; Nephawe, K. A.; Nesanvuni, A. E.; and Benyi, K., 2007. The influence of stocking density on body weight, eggquality, and feed intake of adult broiler breeder hens. Poult. Sci., 86: 1615-1619.

Nagarajan, S.; Narahari, D.; Afred Jayaprasad, I.; and Thy agaragan, D., 1991. Influence of stocking density and layer age on production traits and egg quality in Japanese quail. Brit. Poult. Sci., 32(2): 243-248.

NRC., 1994. Nutrient Requirements of Poultry. 9th Rev.ed. National Academy Press. Washington. DC.

Olawumi Simeon, O., 2015. Carcass Characteristics of Coturnix Quail as Affected by Sex and Housing System. Int. J. Agric. For. Fish., 3(3): 76-79.

Oluyemi, J. A.; and Roberts, Y. O., 1975. The cage versus the deep litter system for the management of layers in the humid tropics. Poult. Sci., 54(6):19821989.

Padmakumar, B.; Reghunanthan Nair, G.; Ramakrishnan, A.; Unni, A. K. K.; and Ravindranathan, N., 2000. Effect of floor space on egg weight and egg quality traits of Japanese quail raised in cages and deep litter. J. Vet. Anim. Sci., 31: 37-39.

Reddy, P. M.; Reddy, V. R.; Reddy, C. V.; and Rep, P. S. P., 1979. Egg weight, shape index and hatchability in khaki Campbell duck egg. Ind. J. Poult. Sci., 14: 26-31.

Roshdy, M.; Khalil, H. A.; Hanafy, A. M.; and Mady, M. E., 2010. Production and reproduction traits of Japanese quail as affected by two housing system. Egypt. Poult. Sci. J., 30(I): 55-67.

Santos, T. C.; Murakami, A. E.; Fanhani, J. C.; and Oliveira, C. A. L.,
2011. Production and reproduction of egg- and meat-type quails reared in different group sizes. Braz. J. Poult. Sci., 13(1): 9-14.

SAS (1998). SAS Users Guide: Statistics. SAS Institute Inc., Cary, NC.

Schmid. I.; and Wechsler, B., 1997. Behaviour of Japanese quail (Coturnix Japonica) kept in semi-natural aviaries. Appl. Anim. Behav. Sci., 55: 103-112.

Seker, I.; Kul, S.; and Bayraktar, M., 2009. Effects of group size on fattening performance, mortality rate, slaughter and carcass characteristics in Japanese quail (Coturnix coturnix japonica). J. Anim. Vet. Advances, 8(4): 688-693.

Sharaf, M. M., 1996. Cage versus floor rearing of Japanese quail as affected by sex, age and bird density. Egypt. Poult. Sci. J., 16(III): 725-738.

Tauson, R., 1998. Health and production in improved cage designs. Poult. Sci., 77: 1820-1827.

Teng, M. F.; Soh, G. L.; and Chew, S. H., 1990. Effects of stocking densities on the productivity of commercial layers in the tropics. Singapore J. Primary Industries, 18(2): 123-128.

Tozluca, A., $1993 . \quad$ Japon BildırcınlarındaFarklıBeslemeS, artlarında CanlıAg ırlıg a Göre Yapılan Seleksiyonun Etkinlig ive Dig er Verimzelliklerine Etkilerizerine BirAras,tırma. ayınlanmamis, Doktora Tezi,S Fen BilimleriEnstitu"su", Konya.

Van Loon, D. P. R.; Hangalapura, B.; De Vries Reilingh, G.; Nieuwland, M. G. B.; Kemp, B.; and Parmentier, H. K., 2004. Effect of three different housing system on immune response and body weight of chicken lines divergently selected for antibody responses to sheep red blood cells. Livest. Prod. Sci., 85: 139-150. 


$$
\begin{aligned}
& \text { الملخص العربي } \\
& \text { تقييم الآداء الانتاجى والتناسلي للسمان الياباني المربح فى الحظائر الارضية وبطاريات الاقفاص }
\end{aligned}
$$

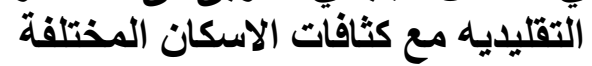

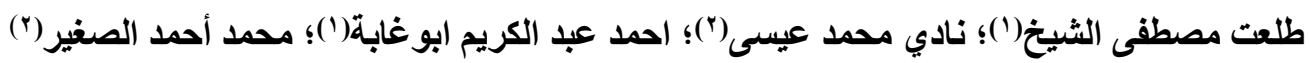

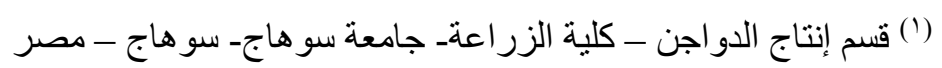

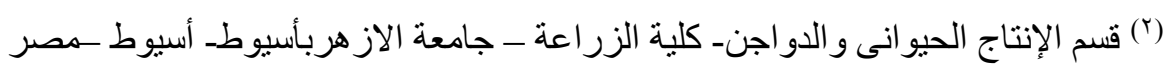

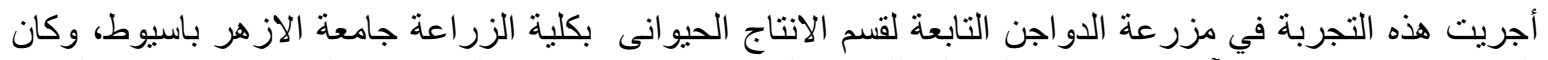

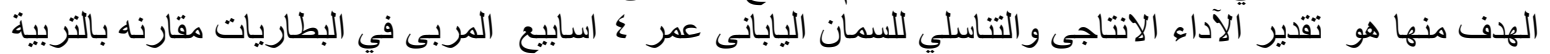

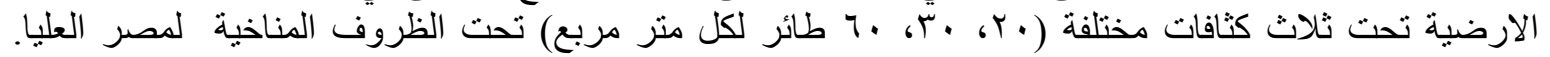

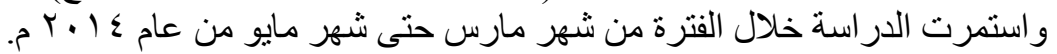

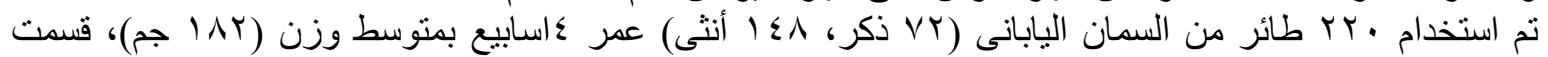

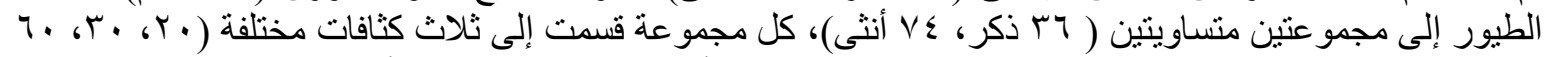

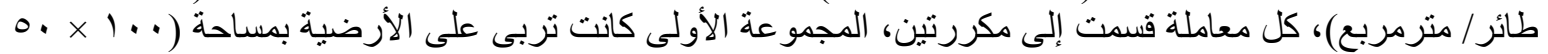

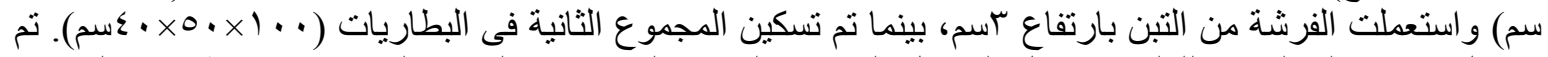

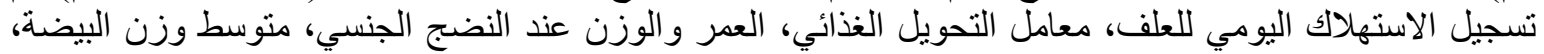

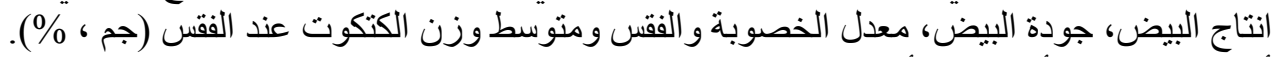

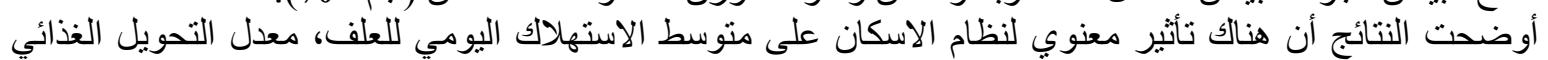

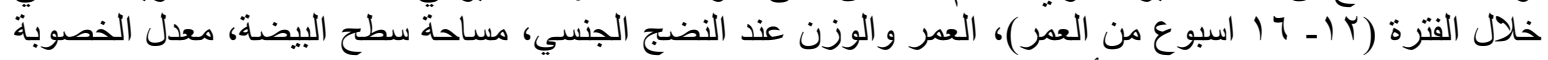

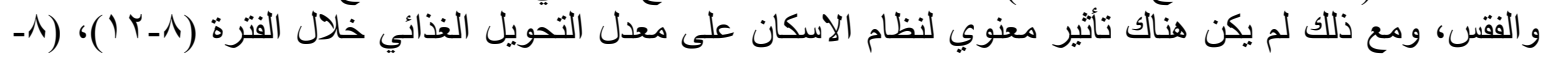

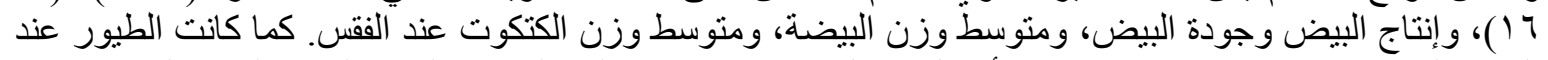

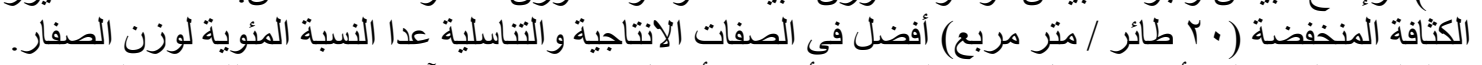

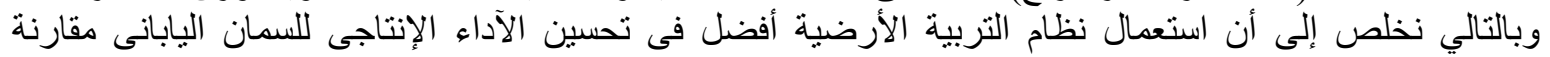

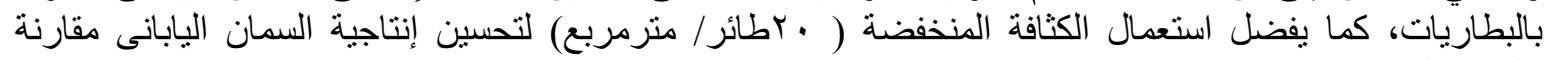
بالكثافة المرتفعة (·ع ، ، ، ج طائر / متر مربع). 